\title{
CUMULATIVE ENVIRONMENTAL IMPACTS AND EXTINCTION RISK OF BRAZILIAN CARNIVORES
}

\author{
Beatriz de Mello Beisiegel
}

Floresta Nacional de Capão Bonito. Rodovia SP 258, km 241, Caixa postal 37, Bairro Itanguá, Capão Bonito, SP, Brasil. CEP: $18300-970$ E-mail: beatriz.beisiegel@icmbio.gov.br

\begin{abstract}
Mammalian carnivores are crucial bioindicators of environmental impacts. Threats to the Brazilian carnivores identified by the national evaluation of extinction risk were reviewed in this article. Native vegetation suppression, road and hydroelectric dam building, mining and petrol extraction are the main threats and are all subjected to laws that require environmental licensing, which should be a safeguard that measures would be adopted to mitigate their negative impacts; however, almost half of the carnivore species are under some degree of extinction threat. This evidences the need for effective enforcement of environmental legislations and for considering cumulative and indirect effects of human activities on carnivore populations. Therefore, the current trends of changes in Brazilian environmental legislation should be reversed in order to avoid biodiversity loss.
\end{abstract}

Keywords: Carnivora; cumulative environmental impacts; Mammalia.

Mammalian carnivores are crucial as bioindicators of environmental impacts because it would be a challenge to find any human impact on the environment that does not represent a threat to these animals. The characteristics of most of these species make them highly vulnerable to environmental changes: they have large home ranges, which are easily reached by some human activity or other (Ripple et al. 2014); they are phylogenetically close to domestic dogs and cats (Agnarsson et al. 2010, Thalmann et al. 2013), being thus sensitive to many of their diseases (Deem et al. 2000, Whiteman et al. 2007, Curi et al. 2010, Megid et al. 2013); they can be attracted by resources offered by human settlements, such as cattle, domestic fowl and garbage (Graham et al. 2005, Penteriani et al. 2016); and they may be hunted for fear, retaliation, or sport (Packer et al. 2011, Swanepoel et al. 2015) even in remote areas. Finally, they have typically high positions in the food chains; therefore, they are indirectly affected by all threats that reach their prey, beyond those on themselves (Ripple et al. 2014).

Native vegetation suppression, road and hydroelectric dam building, mining and petrol extraction cause most of the impacts on carnivore populations. According to the current Brazilian legislation, Federal Law 6.938/81 (Brasil 1981) and
CONAMA Resolutions 1/86, 237/97, 357/2005 and 430/2011 (CONAMA 1986, 1997, 2005, 2011), these activities require environmental licenses by the developers. Thus, the licensing process should be a safeguard that measures would be adopted to mitigate the threats identified in previous studies of environmental impact (EIAs), as indicated by these laws and regulations.

One of the instruments of the National Environment Policy is the national official evaluation of extinction risk. This evaluation was conducted for the Brazilian carnivores in 2011, and published in the form of full assessments in an issue of the journal ‘Biodiversidade Brasileira’ (Beisiegel et al. 2013b). The Brazilian official list with the fauna species in danger of extinction was published in 2014 according to the document "Portaria $n^{\circ} 444$, de 17 de dezembro de 2014" (MMA 2014). Based on the threats to the Brazilian carnivores described in this evaluation, the goal of this paper was to discuss the necessity of the enforcement of environmental legislations, the additional need of evaluating and considering the cumulative and indirect effects of human activities and thus reinforce the risks that the current trends of changes in Brazilian environmental legislation present to these species. 
All the main threats faced by Brazilian carnivores (Table 1) were resumed from the full Brazilian extinction risk assessments and from the global Red List assessments published by the International Union for the Conservation of Nature (IUCN). Most of these threats ( $\mathrm{N}=11$; Table 1$)$ are subjected to some licensing process under the current Brazilian law. Therefore, why are they still threatening a large number of important species?

In the last decades of the $20^{\text {th }}$ century, Brazil developed an advanced environmental legislation, which enforcement, however, is still weak (Drummond \& Barros-Platiau 2006). This implies the idea that, should the environmental legislation be strictly followed, biodiversity would be sufficiently protected to, at least, warrant a sustainable development, which would afford the species protection against the risk of extinction.

This idea could be particularly true to the aspect of environmental legislation which refers to indirect and cumulative impacts. A large number of threats is identified for almost all species of Brazilian carnivores, with the exception of the most unknown Amazonian species, for which habitat loss is the main known threat (Table 1). The species classified as threatened are, each, subjected to five to twelve individual kinds of impacts. None of these impacts is isolated and unidimensional in its effects. All licensed impacts, and many of the consequent impacts, have the effect of generating or increasing other impacts that also are identified as threats to Brazilian carnivores. Therefore, all of these are cumulative impacts, which can be defined as "the synergistic, interactive, or unpredictable outcomes of multiple land-use practices or developments that aggregate over time and space" (Ross 1998, Johnson 2011).

Habitat loss and fragmentation, the most important threat affecting most of the species, has also an incremental effect in almost all of the other identified threats. The effects of cumulative impact of habitat loss for carnivores are well exemplified by the Population Viability Analyses (PVAs) developed for the jaguar, Panthera onca (Desbiez et al. 2012). These analyses concluded that population size and habitat carrying capacity are the main determinants of extinction risk for jaguars. The driver of these variables is mainly habitat fragmentation, which reduces the sizes of jaguar populations. All the impacts that result in decreased carrying capacity of the habitat, such as poaching of jaguar prey species, fire, and introduction of domestic animals that may prey on the same species as jaguars, are also increased by habitat loss and fragmentation. Although eolic energy plants is cited only in the assessment of Puma concolor (Azevedo et al. 2013), this is also one of the major threats to the jaguar $P$. onca at the Caatinga, where eolic plants are being planned at the best area of one of the very few remaining subpopulations of the species (Paula et al. 2012).

Bush dogs (Speothos venaticus) also exemplify clearly the effects of cumulative impacts of habitat loss and fragmentation. Although the animals are able to survive in fragmented landscapes, they forage and rest almost only in native vegetation fragments, using the cultivated matrix mainly for traveling among them (Lima et al. 2014). Their home range in this situation is much larger than in a landscape composed mainly of natural vegetation, which possibly reflects depletion of prey base due to fragmentation and hunting of bush dog preys by humans. The most important causes of death for the groups studied by Lima et al. (2012, 2014) were predation by domestic dogs, killing by humans and probably mange. The loss and fragmentation of the habitat enlarges the necessary home range for one bush dog group, probably decreasing the number of individuals that a region can support; additionally, these supported bush dog groups risk more contact with other threats, due both to the larger area used and the increased penetration of these threats into the dogs' area. The latter are cumulative and indirect impacts of fragmentation.

Although cumulative impacts occur for all Brazilian carnivore species, they are explicitly stated only in the Pampas fox (Lycalopex gymnocercus) IUCN assessment: "However, due to the species' adaptability, the Pampas Fox seems able to withstand the loss and degradation of its natural habitat, as well as hunting pressure. Since no studies are available on its population dynamics in rural ecosystems, caution is required, since the sum of these threats may eventually promote the depletion of fox populations" (Jiménez et al. 2008). 


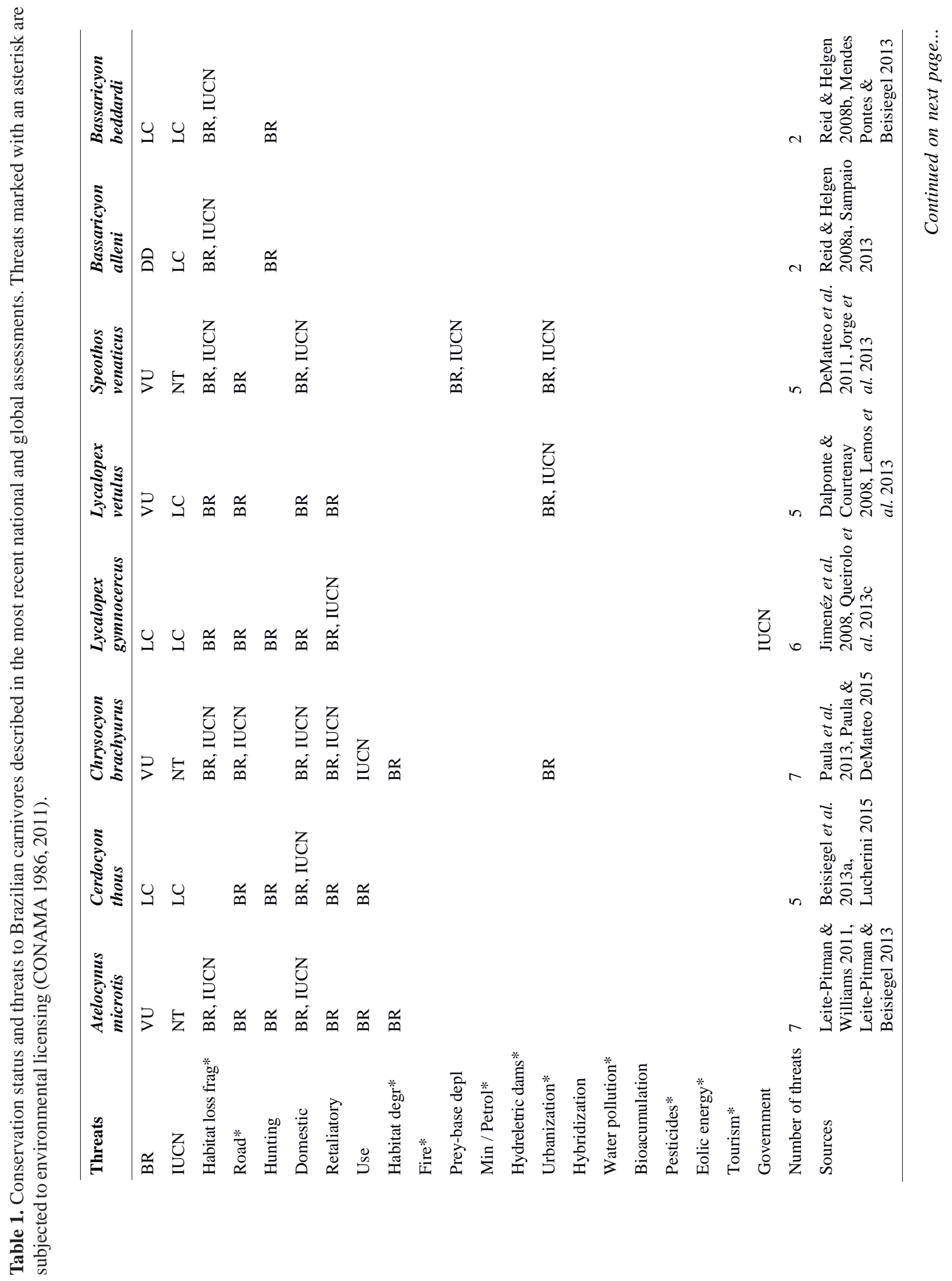




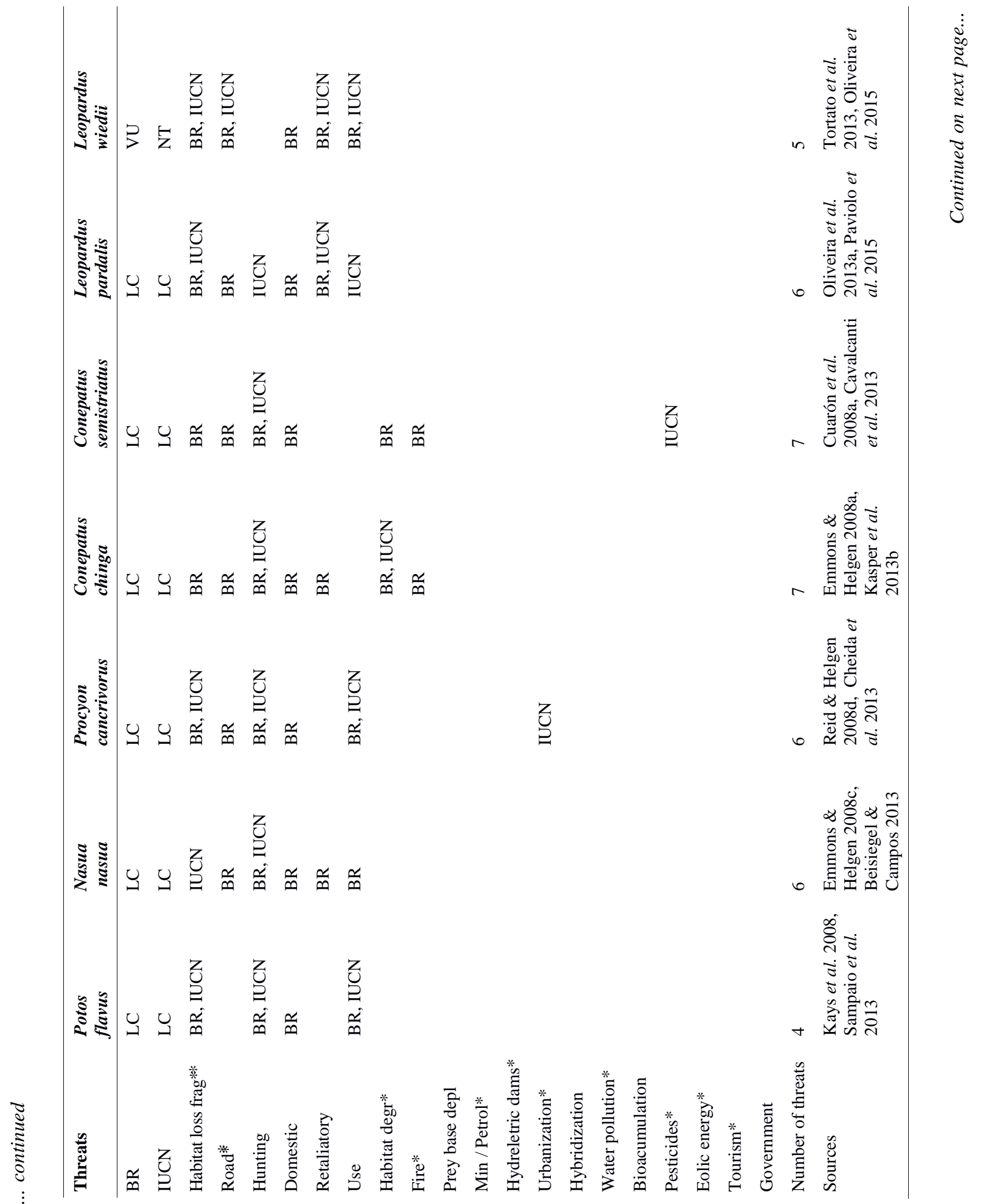




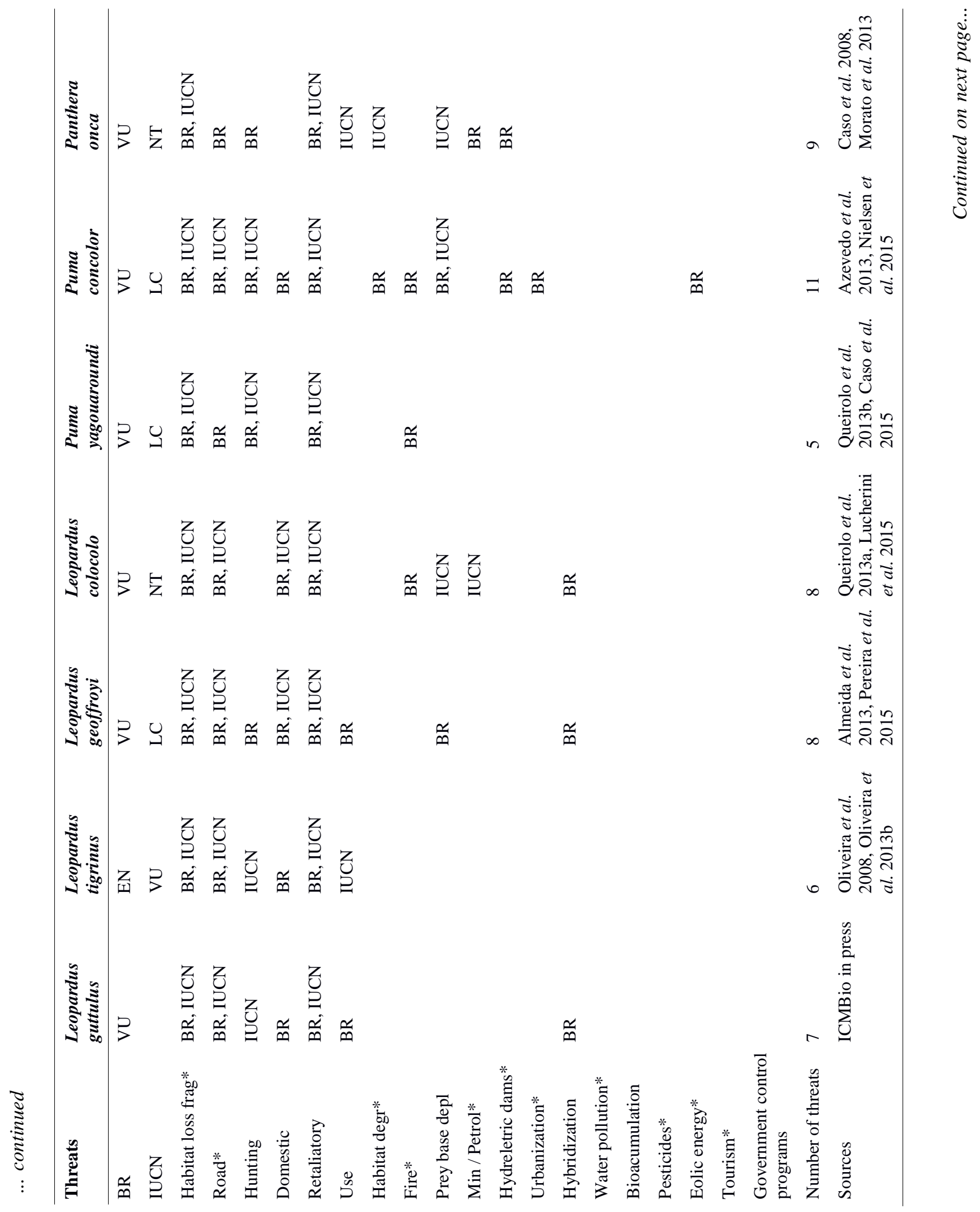




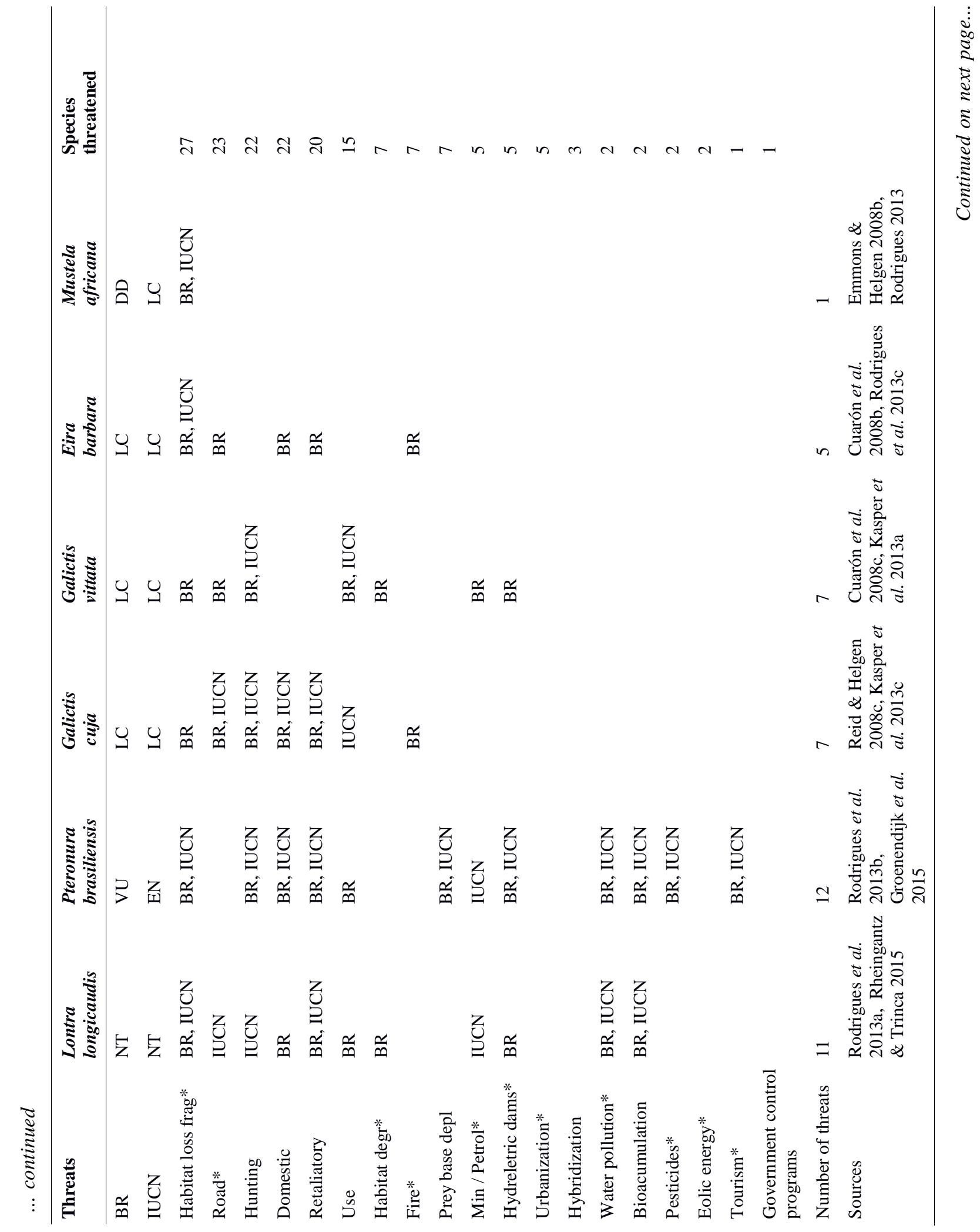




\section{... continued}

BR - extinction risk category in the last National evaluation; IUCN - extinction risk category in the last global IUCN evaluation; Habitat loss frag - Habitat loss includes deforestation and conversion of open areas to croplands and pastures; Road - mainly roadkills, but also road infrastructure expansion; Hunting - includes hunting for sport, food and fear, which can be real (e.g., fear of big cats) or superstition (e.g., fear that olingos or kincajous will attack a person's neck at night to drink blood); Domestic - domestic animal-related impacts: diseases from domestic animals, killing by domestic dogs and cats and competition with domestic animals; Retaliatory - Retaliatory killing; Use - animals taken for pets, either by local communities or by traffic, or killed for pelts or other body parts; Habitat degr - Loss of habitat carrying capacity and habitat degradation, applying to legal or illegal selective extrativism, overgrazing and soil compactation and, for some species, including depletion of prey base; Fire - legal fire used to clear agricultural areas and accidental or criminal large scale fires. Beyond its risks to the animals, fire causes habitat suppression and depletion of prey base; Prey base depl - Prey base depletion; Min/Petrol - mining and petrol extraction; Bioacumulation refers to mercury and other heavy metals along the food chain; Pesticides - carnivores that feed in or near agricultural areas can be directly killed by pesticides used in this cultures; Eolic energy plants - although they represent a renewable energy source, their implantation represents a large-scale impact; Tourism - poorly planned tourism may cause animals to abandon their home ranges and may create or enhance conflicts between carnivores and people. Threat categories: LC - Least Concern; NT - Near Threatened; DD - Data Deficient; VU - Vulnerable; EN - Endangered.

Analysis of indirect and cumulative effects is required by the CONAMA resolution 1/86 (CONAMA 1986), but according to Glasson \& Salvador (2000) "secondary, indirect, and cumulative impacts are also not well identified or properly assessed" in Brazilian EIAs. These analyses are already implemented in some countries such as in the European Union, Canada and United States, and in all countries there is recognition that they are a complex issue and in most cases are only perfunctorily performed (CEQ 1997, Walker \& Johnston 1999, Glasson et al. 2005, Gunn et al. 2011). However, the importance and magnitude of the cumulative impacts, despite the difficulty in its assessment, led to the elaboration of guidelines (CEQ 1997, Walker \& Johnston 1999) and a book on cumulative impact mitigation (Krausman \& Harris 2011).

Building and paving of roads are the best demonstration that the isolated assessment of environmental impacts of a development may be almost irrelevant on the context of all changes promoted by it. Roads are the second most important threat to Brazilian carnivores, considering the number of species affected (22 species, see Table 1), and one of the most important drivers of biodiversity loss around the world. However, assessments of impacts of roads are frequently limited in scope, focusing only on the direct effects of road building (Laurance et al. 2014). Other effects, such as promoting habitat loss and facilitating human access with consequent increases of hunting, prey base depletion, urbanization, human-wildlife conflicts and consequent retaliatory hunting, fires, and loss of carnivore lives due to predation by or diseases acquired from domestic carnivores, which are indirect and cumulative effects of roads, may be even more important as threats than the habitat lost or disrupted by the road. Of the 23 carnivore species threatened by roads, 17 are also affected by hunting, 20 by domestic animals, 19 by retaliatory killing, seven by fire, six by prey base depletion and five by urbanization. One species, the cougar $P$. concolor, is even threatened by all of these impacts, so an analysis of the impact of road building or enlarging in a population of these species should clearly contemplate all these effects.

The advancements made on the last century by Brazil environmental legislation (Drummond \& BarrosPlatiau 2006) are currently being challenged by economic interests, with the recent example of replacement of the 1965 Forest Code (Brasil 1965) by the Law 12.651/2012 (Brasil 2012), which weakens considerably the protection to native vegetation. One of these challenges is the Proposal of Constitutional Amendment (PEC) 65/2012, which eliminates the process of environmental licensing, substituting it by the simple presentation of the Environmental Impact Assessment, when, in contrast, the example of the Brazilian carnivores is just one of many cases in which environmental protection laws should be strengthened and more rigorously observed in order to avoid risks of biodiversity loss.

\section{REFERENCES}

Agnarsson, I., Kuntner, M., \& May-Collado, L. J. 2010. Dogs, cats, and kin: a molecular species-level phylogeny of Carnivora. Molecular Phylogenetics and Evolution, 54(3), 726-745. DOI: 10.1016/j.ympev.2009.10.033 
Almeida, L. B., Queirolo, D., de Oliveira, T. G., Beisiegel, B. M. 2013. Avaliação do risco de extinção do gato-do-mato Leopardus geoffroyi (d'Orbigny Gervais, 1844) no Brasil. Biodiversidade Brasileira, 2013(1), 84-90.

Azevedo, F. C., Lemos, F. G., de Almeida, L. B., de Campos, C. B., Beisiegel, B. M., Paula, R. C., Crawshaw Jr, P. G. , Ferraz, K. M. M. B., Oliveira, T. G. 2013. Avaliação do risco de extinção da onça-parda Puma concolor (Linnaeus, 1771) no Brasil. Biodiversidade Brasileira, 2013(1), 107-121.

Beisiegel, B. M. \& Campos, C. B. 2013. Avaliação do risco de extinção do quati Nasua nasua (Linnaeus, 1766) no Brasil. Biodiversidade Brasileira, 2013(1), 269-276.

Beisiegel, B. M., Lemos, F. G., de Azevedo, F. C., Queirolo, D., Pinto, R. S. 2013a. Avaliação do risco de extinção do cachorrodo-mato Cerdocyon thous (Linnaeus, 1766) no Brasil. Biodiversidade Brasileira, 2013(1), 138-145.

Beisiegel, B. M., Morato, R. G., Paula, R. C., Gasparini-Morato, R. L. 2013b. Apresentação da avaliação do estado de conservação dos carnívoros. Biodiversidade Brasileira, 2013(1), 54-55.

Brasil. 1965. Presidência da República. Lei 4.771, de 15 de Setembro de 1965. Institui o novo Código Florestal. http:// www.planalto.gov.br/ccivil 03/leis/L4771.htm (Retrieved in September 28, 2016).

Brasil. 1981. Presidência da República. Lei 6.938, de 31 de agosto de 1981. Dispõe sobre a Política Nacional do Meio Ambiente, seus fins e mecanismos de formulação e aplicação, e dá outras providências. http://www.planalto.gov.br/ccivil_03/leis/ L6938.htm. (Retrieved in September 28, 2016).

Brasil. 2012. Presidência da República, Casa Civil. Lei 12.651, de 25 de maio de 2012. Dispõe sobre a proteção à vegetação nativa. http://www.planalto.gov.br/ccivil_03/_Ato2011-2014/ 2012/Lei/L12651.htm. (Retrieved in September 28, 2016)

Caso, A., Lopez-Gonzalez, C., Payan, E., Eizirik, E., de Oliveira, T., Leite-Pitman, R., Kelly, M., Valderrama, C. 2008. Panthera onca. The IUCN Red List of Threatened Species 2008: e.T15953A5327466. DOI: 10.2305/IUCN.UK.2008.RLTS. T15953A5327466.en.

Caso, A., de Oliveira, T., \& Carvajal, S. V. 2015. Herpailurus yagouaroundi. The IUCN Red List of Threatened Species 2015: e.T9948A50653167. DOI: 10.2305/IUCN.UK.20152.RLTS.T9948A50653167.en.

Cavalcanti, G. N., Rodrigues, M. L.F., Rodrigues, F. H. G., Rodrigues, L.A. 2013. Avaliação do risco de extinção da jaritataca Conepatus semistriatus (Boddaert, 1785) no Brasil. Biodiversidade Brasileira, 2013 (1), 248-254.

CEQ - Council of Environmental Quality. 1997. Considering cumulative effects under the National Environment Policy Act. Retrieved April 29, 2016, from http://energy.gov/sites/ $\mathrm{prod} /$ files/nepapub/nepa_documents/RedDont/G-CEQConsidCumulEffects.pdf

Cheida, C. C., Guimarães, F. H., \& Beisiegel, B. M. 2013. Avaliação do risco de extinção do guaxinim Procyon cancrivorus (Cuvier, 1798) no Brasil. Biodiversidade Brasileira, 2013(1), 283-290.

CONAMA - Conselho Nacional do Meio Ambiente. 1986. Ministério do Meio Ambiente. Resolução CONAMA No 001, de 23 de janeiro de 1986. http://www.mma.gov.br/port/conama/ res/res86/res0186.html. (Retrieved in September 28, 2016).

CONAMA-Conselho Nacional do Meio Ambiente. 1997. Ministério do Meio Ambiente. Resolução CONAMA No 237, de 19 de dezembro de 1997.http://www.mma.gov.br/port/conama/res/ res97/res23797.html. (Retrieved in September 28, 2016).

CONAMA-Conselho Nacional do Meio Ambiente. 2005. Ministério do Meio Ambiente. Resolução CONAMAN 357 , de 17 de março de 2005. http://www.siam.mg.gov.br/sla/download.pdf?id Norma $=2747$ (Retrieved in September 28, 2016).

CONAMA - Conselho Nacional do Meio Ambiente. 2011. Ministério do Meio Ambiente. Resolução CONAMA No 430, de 13 de maio de 2011. http://www.mma.gov.br/port/conama/ legiabre.cfm?codlegi=646 (Retrieved in September 28, 2016).

Cuarón, A. D., Reid, F., Helgen, K. 2008a. Conepatus semistriatus. The IUCN Red List of Threatened Species 2008: e.T41633A10524231. DOI: 10.2305/IUCN.UK.2008. RLTS.T41633A10524231.en. (Retrieved in April 7, 2016).

Cuarón, A.D., Reid, F., \& Helgen, K. 2008b. Eira barbara. The IUCN Red List of Threatened Species 2008: e.T41644A10526741. DOI:10.2305/IUCN.UK.2008. RLTS.T41644A10526741.en.

Cuarón, A.D., Reid, F., \& Helgen, K. 2008c. Galictis vittata. The IUCN Red List of Threatened Species 2008: e.T41640A10525769. DOI:10.2305/IUCN.UK.2008.RLTS. T41640A10525769.en.

Curi, N. H. A., Araújo, A. S., Campos, F. S., Lobato, Z. I. P., Gennari, S. M., Marvulo, M. F. V., Silva, J. C. R., Talamoni, S. A. 2010. Wild canids, domestic dogs and their pathogens in Southeast Brazil: disease threats for canid conservation. Biodiversity and Conservation, 19(12), 3513-3524. DOI: 10.1007/s10531-010-9911-0

Dalponte, J. \& Courtenay, O. 2008. Pseudalopex vetulus. The IUCN Red List of Threatened Species 2008: e.T6926A12815527. DOI: 10.2305/IUCN.UK.2008.RLTS. T6926A12815527.en.

Deem, S. L., Spelman, L. H., Yates, R. A., Montali, R. J. 2000. Canine distemper in terrestrial carnivores: a review. Journal of Zoo and Wildlife Medicine, 31(4), 441-451.

DeMatteo, K., Michalski, F., \& Leite-Pitman, M. R. P. 2011. Speothos venaticus. The IUCN Red List of Threatened Species 2011: e.T20468A9203243. DOI: 10.2305/IUCN.UK.20112.RLTS.T20468A9203243.en.

Desbiez, A. L., Traylor-Holzer, K., Lacy, B., Beisiegel, B. M., Breitenmoser-Würsten, C., Sana, D. A., Moraes Jr, E. A., Carvalho Jr. E. A. , Lima, F. , Boulhosa, , R., Paula, R. C, Morato, R. G., Cavalcanti, S. M. C. Oliveira, T. G. 2012. Population Viability Analysis of jaguar populations in Brazil. Cat News Special Issue, 7, 35-37.

Drummond, J. \& Barros-Platiau, A. F. 2006. Brazilian environmental laws and policies, 1934-2002: a critical overview. Law \& Policy, 28(1), 83-108.

Emmons, L. \& Helgen, K. 2008a. Conepatus chinga. The IUCN Red List of Threatened Species 2008: e.T41630A10523582. DOI: 10.2305/IUCN.UK.2008.RLTS.T41630A10523582.en.

Emmons, L. \& Helgen, K. 2008b. Mustela africana. The IUCN Red List of Threatened Species 2008: e.T14025A4384743. DOI: 10.2305/IUCN.UK.2008.RLTS.T14025A4384743.en. 
Emmons, L. \& Helgen, K. 2008c. Nasua nasua. The IUCN Red List of Threatened Species 2008: e.T41684A10511324. DOI: 10.2305/IUCN.UK.2008.RLTS.T41684A10511324.en.

Glasson, J., Therivel, R., \& Chadwick, A. 2005. Introduction to Environmental Impact Assessment. 3rd ed. London: Routledge: p. 448.

Glasson, J., \& Salvador, N. N. B. 2000. EIA in Brazil: a procedurespractice gap. A comparative study with reference to the European Union, and especially the UK. Environmental Impact Assessment Review, 20(2), 191-225.

Graham, K., Beckerman, A. P., Thirgood, S. 2005. Humanpredator-prey conflicts: ecological correlates, prey losses and patterns of management. Biological Conservation, 122(2), 159-171.

Groenendijk, J., Duplaix, N., Marmontel, M., Van Damme, P., Schenck, C. 2015. Pteronura brasiliensis. The IUCN Red List of Threatened Species 2015: e.T18711A21938411. DOI: 10.2305/IUCN.UK.2015-2.RLTS.T18711A21938411.en.

Gunn, A., Johnson, C. J., Nishi, J. S., Daniel, C. J., Russell, D. E., Carlson, M., Adamczewski, J. Z. 2011. Understanding the cumulative effects of human activities on barren-ground caribou. In: P. R Krausman \& L.K. Harris (Eds.) Cumulative effects in wildlife management: impact mitigation. pp. 113134. Boca Raton, Florida: CRC Press.

Jiménez, J. E., Lucherini, M., \& Novaro, A.J. 2008. Pseudalopex gymnocercus. The IUCN Red List of Threatened Species 2008: e.T6928A12816086. DOI: $10.2305 /$ IUCN.UK. 2008.RLTS.T6928A12816086.en.

Johnson, C. J. 2011. Regulating and Planning for Cumulative Effects. In: P. R Krausman \& L. K. Harris (Eds.) Cumulative effects in wildlife management: impact mitigation. pp. 29-46. Boca Raton, Florida: CRC Press.

Jorge, R. P. S., Beisiegel, B. M., Lima, E. S., Jorge, M. L. D. S. P., Leite-Pitman, M. R. P., de Paula, R. C. 2013. Avaliação do risco de extinção do cachorro-vinagre Speothos venaticus (Lund, 1842) no Brasil. Biodiversidade Brasileira, 2013(1), 179-190.

Kasper, C. B., Bornholdt, R., \& Rodrigues, L. A. 2013a. Avaliação do risco de extinção do furão-grande Galictis vittata (Schreber, 1776) no Brasil. Biodiversidade Brasileira, 2013(1), 211-215.

Kasper, C. B., da Cunha, F. P., \& da Fontoura-Rodrigues, M. L. 2013b. Avaliação do risco de extinção do zorrilho Conepatus chinga (Molina, 1782) no Brasil. Biodiversidade Brasileira, 2013(1), 240-247.

Kasper, C. B., Leuchtenberger, C., Bornholdt, R., Pontes, A. R. M., Beisiegel, B. M. 2013c. Avaliação do risco de extinção do furão Galictis cuja (Molina, 1782) no Brasil. Biodiversidade Brasileira, 2013(1), 203-210.

Kays, R., Reid, F., Schipper, J. Helgen, K. 2008. Potos flavus. The IUCN Red List of Threatened Species 2008: e.T41679A10507696. http://dx.doi.org/10.2305/ IUCN.UK.2008.RLTS.T41679A10507696.en.

Krausman, P. R, \& Harris, L. K. (Eds.) 2011. Cumulative Effects in Wildlife Management: Impact Mitigation. Boca Raton, Florida: CRC Press. p. 274.

Laurance, W. F., Clements, G. R., Sloan, S., O'Connell, C. S., Mueller, N. D., Goosem, M., Venter, O., Edwards, D. P., Phalan, B., Balmford, A., Van Der Ree, R., Arreas, I. B. 2014. Aglobal strategy for road building. Nature, 513(7517), 229-232.

Leite-Pitman, M. R. P., \& Williams, R. S. R. 2011. Atelocynus microtis. The IUCN Red List of Threatened Species 2011: e.T6924A12814890. DOI: 10.2305/IUCN.UK.20112.RLTS.T6924A12814890.en.

Leite-Pitman, R., \& Beisiegel, B. M. 2013. Avaliação do risco de extinção do cachorro-do-mato-de-orelhas-curtas Atelocynus microtis (Sclater, 1883) no Brasil. Biodiversidade Brasileira, 2013(1), 133-137.

Lemos, F. G., de Azevedo, F. C., Beisiegel, B. M., Jorge, R. P. S., de Paula, R. C., Rodrigues, F. H. G., Rodrigues, L. A. 2013. Avaliação do risco de extinção da Raposa-do-campo Lycalopex vetulus (Lund, 1842) no Brasil. Biodiversidade Brasileira, 2013(1), 160-171.

Lima, E.S., DeMatteo, K. E., Jorge, R. S., Jorge, M. L. S., Dalponte, J. C., Lima, H. S., Klorfine, S. A. 2012. First telemetry study of bush dogs: home range, activity and habitat selection. Wildlife Research, 39(6), 512-519. DOI: 10.1071/WR11176

Lima, E. S., Jorge, M. L. S., Jorge, R. S., Morato, R. G. 2014. The bush dog Speothos venaticus: area requirement and habitat use in cultivated lands. Oryx, 49(01), 64-70. DOI: 10.1017/ S0030605314000076

Lucherini, M. 2015. Cerdocyon thous. The IUCN Red List of Threatened Species 2015: e.T4248A81266293. DOI: 10.2305/ IUCN.UK.2015-4.RLTS.T4248A81266293.en.

Lucherini, M., Eizirik, E., de Oliveira, T., Pereira, J. Wallace, R. 2015. Leopardus colocolo. The IUCN Red List of Threatened Species 2015: e.T15309A50656743. DOI: 10.2305/ IUCN.UK.2015-4.RLTS.T15309A50656743.en.

Megid, J., Teixeira, C. R., Cortez, A., Heinemann, M. B., Antunes, J. M., Fornazari, F., Rassy, R. B., Richtzenhain, L. J. 2013. Canine distemper virus infection in a lesser grison (Galictis cuja): first report and virus phylogeny. Pesquisa Veterinária Brasileira, 33(2), 247-250. DOI: 10.1590/S0100-736X2013000200018

Mendes Pontes, A. R., \& Beisiegel, B. M. 2013. Avaliação do risco de extinção do gogó-de-sola Bassaricyon beddardi (Pocock, 1921) no Brasil. Biodiversidade Brasileira, 2013(1), 260-265.

MMA. 2014. Ministério do Meio Ambiente. Portaria MMA n ${ }^{\circ}$ 444, de 17 de Dezembro de 2014. Reconhece a Lista Nacional Oficial de espécies da fauna ameaçadas de extinção. Diário Oficial da União, $\mathrm{n}^{\circ}$ 245, quinta-feira, 18 de dezembro de 2014, seção 1, p.121-126. (Retrieved in September 28, 2016). Morato, R. G., Beisiegel, B. M., Ramalho, E. E., de Campos, C. B., Boulhosa, R. L. P. 2013. Avaliação do risco de extinção da onça-pintada Panthera onca (Linnaeus, 1758) no Brasil. Biodiversidade Brasileira, 2013 (1), 122-132.

Nielsen, C., Thompson, D., Kelly, M. Lopez-Gonzalez, C.A. 2015. Puma concolor. The IUCN Red List of Threatened Species 2015: e.T18868A50663436. DOI: 10.2305/IUCN. UK.2015-4.RLTS.T18868A50663436.en.

Oliveira, T. G., de Almeida, L. B., de Campos, C. B. 2013a. Avaliação do risco de extinção da jaguatirica Leopardus pardalis (Linnaeus, 1758) no Brasil. Biodiversidade Brasileira, 2013(1), 66-75.

Oliveira, T. G., Tortato, M. A., de Almeida, L. B., de Campos, C. B., Beisiegel, B. M. 2013b. Avaliação do risco de extinção do gato-do-mato Leopardus tigrinus no Brasil. Biodiversidade Brasileira, 2013(1), 56-65. 
Oliveira, T., Eizirik, E., Schipper, J., Valderrama, C., Leite-Pitman, R., Payan, E. 2008. Leopardus tigrinus. The IUCN Red List of Threatened Species 2008: e.T11510A3289293. DOI: 10.2305/IUCN.UK.2008.RLTS.T11510A3289293.en.

Oliveira, T., Paviolo, A., Schipper, J., Bianchi, R., Payan, E., Carvajal, S.V. 2015. Leopardus wiedii. The IUCN Red List of Threatened Species 2015: e.T11511A50654216. DOI: 10.2305/IUCN.UK.2015-4.RLTS.T11511A50654216.en.

Packer, C., Brink, H., Kissui, B. M., Maliti, H., Kushnir, H., Caro, T. 2011. Effects of trophy hunting on lion and leopard populations in Tanzania. Conservation Biology, 25(1), 142-153.

Paula, R. C., \& DeMatteo, K. 2015. Chrysocyon brachyurus. The IUCN Red List of Threatened Species 2015: e.T4819A82316878. DOI: 10.2305/IUCN.UK.20154.RLTS.T4819A82316878.en.

Paula, R. C., Rodrigues, F. H. G., Queirolo, D., Jorge, R. P. S., Lemos, F. G., Rodrigues, L. A. 2013. Avaliação do risco de extinção do lobo-guará Chrysocyon brachyurus (Illiger, 1815) no Brasil. Biodiversidade Brasileira, 2013(1), 146-159.

Paula, R. C., Campos, C. B., \& Oliveira, T. G. 2012. Red list assessment for the jaguar in the Caatinga Biome. Cat News Special Issue, 7, 19-24.

Paviolo, A., Crawshaw, P., Caso, A., de Oliveira, T., LopezGonzalez, C. A., Kelly, M., De Angelo, C., Payan, E. 2015. Leopardus pardalis. The IUCN Red List of Threatened Species 2015: e.T11509A50653476. DOI: 10.2305/ IUCN.UK.2015-4.RLTS.T11509A50653476.en.

Penteriani, V., Delgado, M. del M., Pinchera, F., Naves, J., FernándezGil, A., Kojola, I., Härkönen, S., Norberg, H., Frank, J., Fedriani, J. M., Sajlén, V., Støen, O., Swenson, J. E., Wabakken, P., Pellegrini, M., Herrero, S., López-Bao, J. V. 2016. Human behaviour can trigger large carnivore attacks in developed countries. Scientific Reports, 6, 20552. DOI: 10.1038/srep20552

Pereira, J., Lucherini, M., Trigo, T. 2015. Leopardus geoffroyi. The IUCN Red List of Threatened Species 2015: e.T15310A50657011. DOI: 10.2305/IUCN.UK.20152.RLTS.T15310A50657011.en.

Queirolo, D., Almeida, L. B., Beisiegel, B. M., Oliveira, T. G. 2013a. Avaliação do risco de extinção do gato-palheiro Leopardus colocolo (Molina, 1782) no Brasil. Biodiversidade Brasileira, 2013(1), 91-98.

Queirolo, D., Beisiegel, B. M., \& Oliveira, T. G. 2013b. Avaliação do risco de extinção do gato-mourisco Puma yagouaroundi (É. Geoffroy Saint-Hilaire, 1803) no Brasil. Biodiversidade Brasileira, 2013(1), 99-106.

Queirolo, D., Kasper, C. B., \& Beisiegel, B. M. 2013c. Avaliação do risco de extinção do graxaim-do-campo Lycalopex gymnocercus (G. Fischer, 1814) no Brasil. Biodiversidade Brasileira, 2013(1), 172-178.

Reid, F., \& Helgen, K. 2008a. Bassaricyon alleni. The IUCN Red List of Threatened Species 2008: e.T41678A10507340. DOI: 10.2305/IUCN.UK.2008.RLTS.T41678A10507340.en.

Reid, F., \& Helgen, K. 2008b. Bassaricyon beddardi. The IUCN Red List of Threatened Species 2008: e.T2610A9460975. DOI: 10.2305/IUCN.UK.2008.RLTS.T2610A9460975.en

Reid, F., \& Helgen, K. 2008c. Galictis cuja. The IUCN Red List of Threatened Species 2008: e.T41639A10525484. DOI:
10.2305/IUCN.UK.2008.RLTS.T41639A10525484.en.

Reid, F., \& Helgen, K. 2008d. Procyon cancrivorus. The IUCN Red List of Threatened Species 2008: e.T41685A10511865. DOI: 10.2305/IUCN.UK.2008.RLTS.T41685A10511865.en..

Rheingantz, M. L., \& Trinca, C. S. 2015. Lontra longicaudis. The IUCN Red List of Threatened Species 2015: e.T12304A21937379. DOI: 10.2305/IUCN.UK.20152.RLTS.T12304A21937379.en.

Ripple, W. J., Estes, J. A., Beschta, R. L., Wilmers, C. C., Ritchie, E. G., Hebblewhite, M., Berger, J., Elmhagen, B., Letnik, M., Nelson, M. P., Schmitz, O. J., Shmitz, D. W., Wallach, A. D. Wirsing, A. J. 2014. Status and ecological effects of the world's largest carnivores. Science, 343(6167), 1241484. DOI: 10.1126/science.1241484

Rodrigues, L. A. 2013. Avaliação do risco de extinção da doninhaamazônica Mustela africana (Desmarest, 1818) no Brasil. Biodiversidade Brasileira, 2013(1), 191-194.

Rodrigues, L. A., Leuchtenberger, C., Kasper, C. B., Junior, O. C., da Silva, V. C. F. 2013a. Avaliação do risco de extinção da lontra neotropical Lontra longicaudis (Olfers, 1818) no Brasil. Biodiversidade Brasileira, 2013(1), 216-227.

Rodrigues, L. A., Leuchtenberger, C., da Silva, V. C. F. 2013b. Avaliação do risco de extinção da ariranha Pteronura brasiliensis (Zimmermann, 1780) no Brasil. Biodiversidade Brasileira, 2013(1), 228-239.

Rodrigues, L. A., Pontes, A. R. M., \& Rocha-Campos, C. C. 2013c. Avaliação do risco de extinção da irara Eira barbara (Linnaeus, 1758) no Brasil. Biodiversidade Brasileira, 2013(1), 195-202.

Ross, W. A. 1998. Cumulative effects assessment: learning from Canadian case studies. Impact Assessment and Project Appraisal, 16(4), 267-276.

Sampaio, R. 2013. Avaliação do risco de extinção do janaú Bassaricyon alleni (O. Thomas, 1880) no Brasil. Biodiversidade Brasileira, 2013(1), 255-259.

Sampaio, R., Beisiegel, B. M., Pontes, A. R. M. 2013. Avaliação do risco de extinção do jupará Potos flavus (Schreber, 1774) no Brasil. Biodiversidade Brasileira, 2013(1), 277-28.

Swanepoel, L. H., Somers, M. J., \& Dalerum, F. 2015. Functional responses of retaliatory killing versus recreational sport hunting of leopards in South Africa. PloS one, 10(4), e0125539. DOI:10.1371/journal.pone.0125539.

Thalmann, O., Shapiro, B., Cui, P., Schuenemann, V. J., Sawyer, S. K., Greenfield, D. L., Germonpré., M. B., Sablin, M. V., López-Giráldez,, F., Domingo-Roura, X., Napierala, H., Uerpmann, H. P., Loponte, M. P., Acosta, A., Giemsch, L., Schmitz, R. W., Worthington, B., Buikstra, J. E., Druzhkova, A., Graphodatsky, A. S., Ovodov, N. D., Wahlberg, N., Freedman, A. H., Schweizer, R., Koepfli, K., Leonard, J. A., Meyer, M., Krause, J., Pääbo, S., Green, R., Wayne, R. K. 2013. Complete mitochondrial genomes of ancient canids suggest a European origin of domestic dogs. Science, 342 (6160), 871-874. DOI: 10.1126/science.1243650

Tortato, M. A., Oliveira, T. G., Almeida, L. B., Beisiegel, B. M. 2013. Avaliação do risco de extinção do gato-maracajá Leopardus wiedii (Schinz, 1821) no Brasil. Biodiversidade Brasileira, 2013(1), 76-83.

Walker, L.J. \& Johnston, J. 1999. Guidelines for the Assessment of Indirect and Cumulative Impacts as well as Impact 
Interactions. Retrieved from .http://ec.europa.eu/environment/ archives/eia/eia-studies-and-reports/pdf/guidel.pdf.

Whiteman, C. W., Matushima, E. R., Confalonieri, U. E. C., Palha, M. D. D. C., da Silva, A. D. S. L., Monteiro, V. C. 2007.
Human and domestic animal populations as a potential threat to wild carnivore conservation in a fragmented landscape from the Eastern Brazilian Amazon. Biological Conservation, 138(1), 290-296. DOI: 10.1016/j.biocon.2007.04.013

Submitted: 31 May 2016 Accepted: 24 February 2017 